\title{
Health at the time of Native-European contact in Southern Patagonia. First steps, results, and prospects
}

\section{Ricardo Aníbal Guichón ${ }^{+}$, Jorge Alejandro Suby, Romina Casali, Martín Horacio Fugassa}

\author{
Laboratorio de Ecología Evolutiva Humana (Quequén), Departamento de Arqueología, Facultad de Ciencias Sociales, \\ Universidad Nacional del Centro de la Provincia de Buenos Aires, Calle 508 nº 881 (e/517 y 521), (7631) Quequén, \\ Provincia de Buenos Aires, Argentina and Departamento de Biología, Facultad de Ciencias Exactas y Naturales, Universidad \\ Nacional de Mar del Plata, Argentina
}

The objective of this paper is to present the first steps into the study of health in southern Patagonia during pre and post Native-European contact. Thus, our work has a double purpose. First, to discuss characteristics and relevance of human bone records of southern Patagonia, in order to study health in a population context. Second, to show some new lines of information, which include paleoparasitology, nutritional paleopathologies, and the study of lifestyles from human remains. In this context, we have started working on the first Spanish settlement "Nombre de Jesus", founded in 1584, and with historical documentation of "La Candelaria" Mission in Rio Grande (1896-1931).

Key words: paleopathology - archaeology - southern Patagonia

Knowing about the health of human populations is important to understand their history and lifestyle. In general terms, the recognition of epidemiological changes requires actualistic models, as well as the exploration of the variation in health levels over time and space in order to understand the adaptation processes involved (Wood et al. 1992, Mendonça 2003, Armelagos et al. 2005). The presence of illnesses is mostly the product of the imbalance between individuals and numerous environmental components. Evolutionary ecology turns information about health into an indicator of many diverse aspects of human societies.

The objective of this paper is to present the first steps into the study of health in Southern Patagonia during pre and post Native-European contact. Southern Patagonia can be arbitrarily defined as the region including the provinces of Santa Cruz and Tierra del Fuego in Argentina, and the Magellan region in Chile. Thus, our work has a double aim. First, to discuss characteristics and relevance of human bone records of Southern Pa-tagonia, in order to study health in a population context. Second, to show some new lines of information, which include paleoparasitology, nutritional paleopathologies, and the study of lifestyles from human remains, taking into account the diverse archaeological contexts and historical documentation.

Financial support: SECyT-FONCYT PICT no. 4 13889-20052007, Scientific Research Program between Instituto Canario de Bioantropología (Tenerife, España), Facultad de Ciencias Sociales de la Universidad Nacional del Centro de la Provincia de Buenos Aires, Argentina, SECyT-CONICET-ArgentinaCapes, Fiocruz-Brasil-BR/PA-05/HIV/017

${ }^{+}$Corresponding author: guichon@infovia.com.ar

Received 20 July 2006

Accepted 16 October 2006
Paleopathological analyses are recent in Southern Patagonia. Most works from 1990 to the present (Perez-Perez \& Lalueza 1992, García Moro et al. 1993, Guichón 1995, Aspillaga \& Ocampo 1996, Hernández et al. 1998, Aspillaga et al.1999) have studied oral pathologies and stress indicators in human bones related to high latitude adaptation, using conglomerates of materials poorly defined in terms of space and time. In 1986 we criticized the temporal allocation of the samples to ethnographic groups (Cocilovo \& Guichón 1985-86). Given the complexity and antiquity of these human occupations and the characteristics of the records we suggest: (a) the use of a geographical assignation; (b) a more adjusted analysis of the samples; and (c) other complementary lines of information (Guichón 2002).

Moreover, since the archaeological assemblages differ from the original population, the osteological record requires a careful description before the making of paleoepidemiological models. In this sense, a more detailed analysis of bone collections will allow us to discuss the integrity and reliability of the human record (Wood et al. 1992, Mendonça et al. 2003, Borrero 2004). Our knowledge of ancient ecosystems and organisms is partly controlled by our understanding of preservation and taphonomic factors, which include post-mortem changes as well as deposit conditions (Behrensmeyer \& Hook 1992). Therefore, taphonomy and paleoecology ${ }^{1}$ are strongly interrelated (Behrensmeyer et al. 2000). Although in the last few decades other types of evidence have been explored, the human osteological record are still the most abundant source of information about environment, organisms, and ecosystems from the past (Cutler et al 1999). However, are

\footnotetext{
1 Following Wing et al. (1992:2) we understand by paleoecology ...the study of associations among species and ecological attributes through time...
} 
adaptation processes, short-term population distribution, change in food resources and paleoepidemiological changes detectable in human fossil records in Southern Patagonia? The answer to this question is complex and involves the recognition of taphonomic and preservation issues of human fossil records (Wood et al. 1992) as well as an interpretation within their context (Steckel et al. 2002).

\section{The human bone record}

The process of human exploration and colonization in Patagonia was probably slow, with a discontinuous settlement in time and space. The environmental instability in the Pleistocene-Holocene transition aid to explain the lack of early archaeological records and the slowness of the process of colonization (Borrero 1996, 2005).

We still do not have a thorough knowledge about the remains of the Patagonian native population, which are dispersed in museums in Chile, Argentina, United States, and several European countries. The most important collection lies at the Instituto de la Patagonia in Punta Arenas, Chile. Within the last five years many new findings have been incorporated in that collection. From the catalogues of the museums mentioned above, 562 individuals could be identified (Fig. 1). The degree of completeness is varied; little more than $60 \%$ of the samples have postcranial bones, and only $59 \%$ of the individuals can be geographically located. It is possible to observe that most bones appeared near the coast of Tierra del Fuego. Archeological visibility may be connected to this. Moreover, stable isotope information has been obtained from 69 individuals; DNA studies have been done on 48 samples; and chronological information has been obtained from 25 individuals.

The information available for the older archeological sites in Southern Patagonia shows a terrestrial adaptation (Borrero et al. 2001). As for the Middle Holocene, on the basis of stable isotope works, we have found evidence of strategies based on marine and terrestrial resources. It is worth pointing out that these new studies

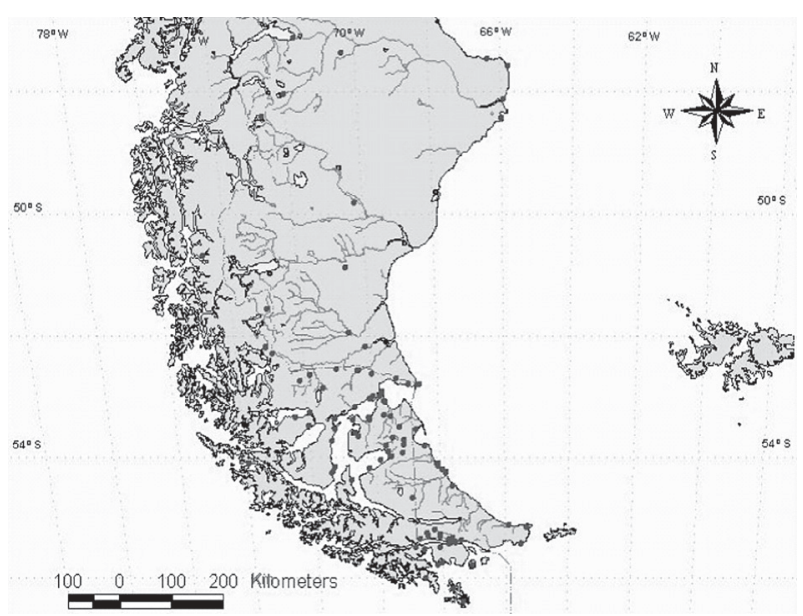

Fig. 1: map of Southern Patagonian human bone collections with geographical reference $(\mathrm{N}=331)$.
(Guichón et al. 2001, Borrero et al. 2001, Barberena 2002) were carried out on some of the same individuals to whom Lalueza (1995) had obtained DNA data. From these analyses, we can see both genetic variability ( $\mathrm{C}$ and $\mathrm{D}$ haplogroup) and dietary variability (marine, mixed, and terrestrial) both in Middle and Late Holocene (Table I, Fig. 2).

Biogeographical characteristics must also be considered. The mountain range of the Andes can be seen as a more or less translucent filter for the genetic flow among populations (Guichón 2000). Moreover, as suggested by Borrero, the Magellan tundra has been characterized by a low current capacity that probably limited the initial size

TABLE I

Genetic and dietary variability for the Middle and Late Holocene

\begin{tabular}{|c|c|c|c|}
\hline & Dietary & $\begin{array}{l}\text { Haplo- } \\
\text { group }\end{array}$ & Chronology \\
\hline \multicolumn{4}{|l|}{ Middle Holocene } \\
\hline 1 Lago Sofía & Terrestrial & $\mathrm{C}$ & 3900BP \\
\hline 2 Marazzi & Terrestrial & $\mathrm{D}$ & $5570 \pm 400 \mathrm{BP}$ \\
\hline 3 Punta Santa Ana & Sea & - & $6800 \mathrm{BP}$ \\
\hline \multicolumn{4}{|l|}{ Late Holocene } \\
\hline 4 Cerro Johnny (B.N.) & Terrestrial & $\mathrm{D}$ & $4000 \mathrm{BP}$ \\
\hline 5 C. Estrecho Trinidad & Sea & $\mathrm{D}$ & $\begin{array}{l}\text { XIX-XX c } \\
\text { (contextual) }\end{array}$ \\
\hline 6 Posesión Olimpia I & Terrestrial & $\mathrm{D}$ & $\begin{array}{r}\text { XIX-XX c } \\
\text { (contextual) }\end{array}$ \\
\hline 7 Puerto Natales & Mixed & $\mathrm{D}$ & $\begin{array}{l}\text { XIX-XX c } \\
\text { (contextual) }\end{array}$ \\
\hline 8 Bahía Santiago & Mixed & $\mathrm{C}$ & $\begin{array}{c}\text { No dating Late } \\
\text { Holocene }\end{array}$ \\
\hline $\begin{array}{l}9 \text { Punta Satélite } \\
\text { (P. Delgada) }\end{array}$ & Mixed & $\mathrm{C}$ & $\begin{array}{c}\text { No dating Late } \\
\text { Holocene }\end{array}$ \\
\hline
\end{tabular}

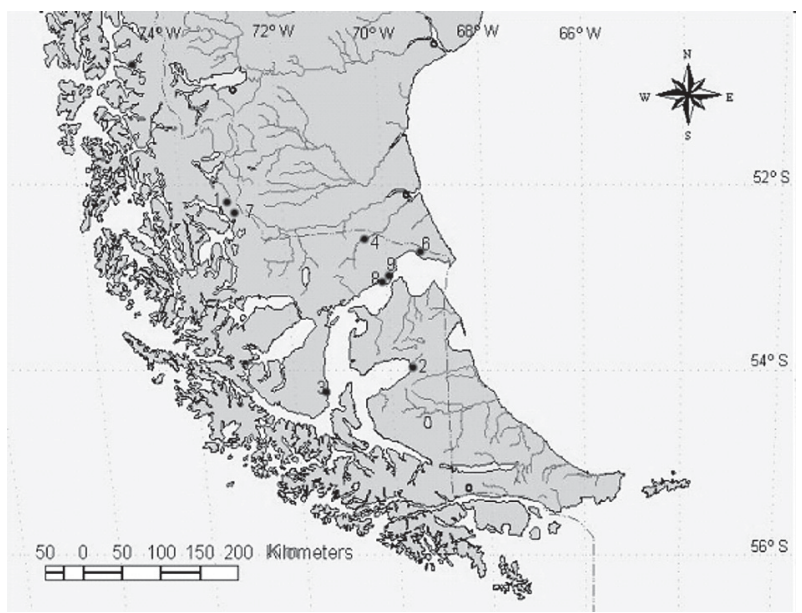

Fig. 2: map of genetic and dietary variability for the Middle and Late Holocene. 
of the human populations. In an environment distinguished by change, climatic pulses, glacial movements, changing sea level, volcanic eruptions, and low demography we cannot discard migratory movements, population isolation, extinction, and reoccupations (Borrero 1996).

In general terms, the biological human record of Southern Patagonia presents the following characteristics: (1) spatial-temporal variability; (2) better visibility and preservation on the coast than in forests and inland areas (Borrero \& Muñoz 1999); (3) on the coast, most bones were found near other types of evidence. Those bones which were found on the surface were dispersed and looked altered (Guichón et al. 2000, Martín et al. 2004, Suby \& Guichón 2004); (4) inland, however, human bones were found only in burial sites (Guichón et al. 2001, Barberena 2002).

These features can be attributed to three fundamental aspects: (a) the ecological characteristics of the populations, which condition their space distribution; (b) the taphonomical processes involved in the region, which transport and possibly destroy the evidence; and (c) the action and relation between these processes and bone properties, such as weight, size and bone mineral density (Cruz 2004). In this sense, Suby is working at the moment on the comparison of densitometrical (DEXA) and tomographical techniques (Fig. 3) to obtain bone mineral density (BMD) value in several archaeological, cultural and environmental contexts in Patagonia (Suby \& Guichón 2004).

\section{Patagonian human health}

The paleopathological studies in Patagonia have included oral pathologies (dental caries, abscesses and tooth loss, dental hypoplasia), nutritional pathologies (criba orbitalia and porotic hyperostosis), some infectious signs like periostitis, and osteoarticular deformations. The general tendencies obtained from the information about lifestyles (Guichon 1995) are consistent with the observations on other hunter-gatherer populations (Lukacs 1989), which reveal low frequencies of caries, high dental erosion, relatively low presence of dental hypoplasia, and porotic hyperostosis. As we have already mentioned, these tendencies observed in Patagonia were estimated from bone collections with little chronological and contextual information. Therefore, these results are considered exploratory and aimed to evaluate variability (Guichón 1995). However, in the last few years, research has moved in three directions. Various research teams have been working on the assessment of temporal, dietary and molecular data (Lalueza 1995, Borrero et al 2001, Barberena 2002, González et al. 2004, Barrientos et al. 2005). In addition, new archaeological assemblages have been found, offering a promising prospect (Barrientos et al. 2005, Garcia Guraieb et al. 2005a,b, Senatore et al. 2005). Moreover, other lines of evidence are being explored, including metabolic bone diseases, structural and cross-sectional alterations due to malnutrition and activity patterns, the study of historical documents, and host-hosted relationships of parasitologies.

Within archeology, paleoparasitology enables us to retrieve information about extinct populations and their environment, their use of the sites, their hygiene, diets and forms of consumption, in addition to the knowledge about parasitosis and health related problems. Up to the present there has been only few records of coprolites in Southern Patagonia. However, our inquiry into the study of coprology has been fruitful, and a considerable amount of samples could be gathered. The joint effort of archaeologists, bioanthropologists, and paleoparasitologists was the key to this success. The coprolite collection corresponds to CCP5 and CCP7 sites, two caves located in Perito Moreno National Park, Santa Cruz, Argentina, which represent an important source of evidence of pre NativeEuropean contact period (10,500 to 3000 years BP approximately) (Fugassa 2005, Fugassa \& Guichón 2005). Among the samples we have found feaces of fauna (camelids, canids, felines, rodents, and other unidentified species), which allow the analysis of the ancient zoonosis. The effect of Native-European contact on the dispersion of parasitic diseases requires research into the presence of parasites in the early stages. These sediments are useful to the study of both pre and post-contact periods.
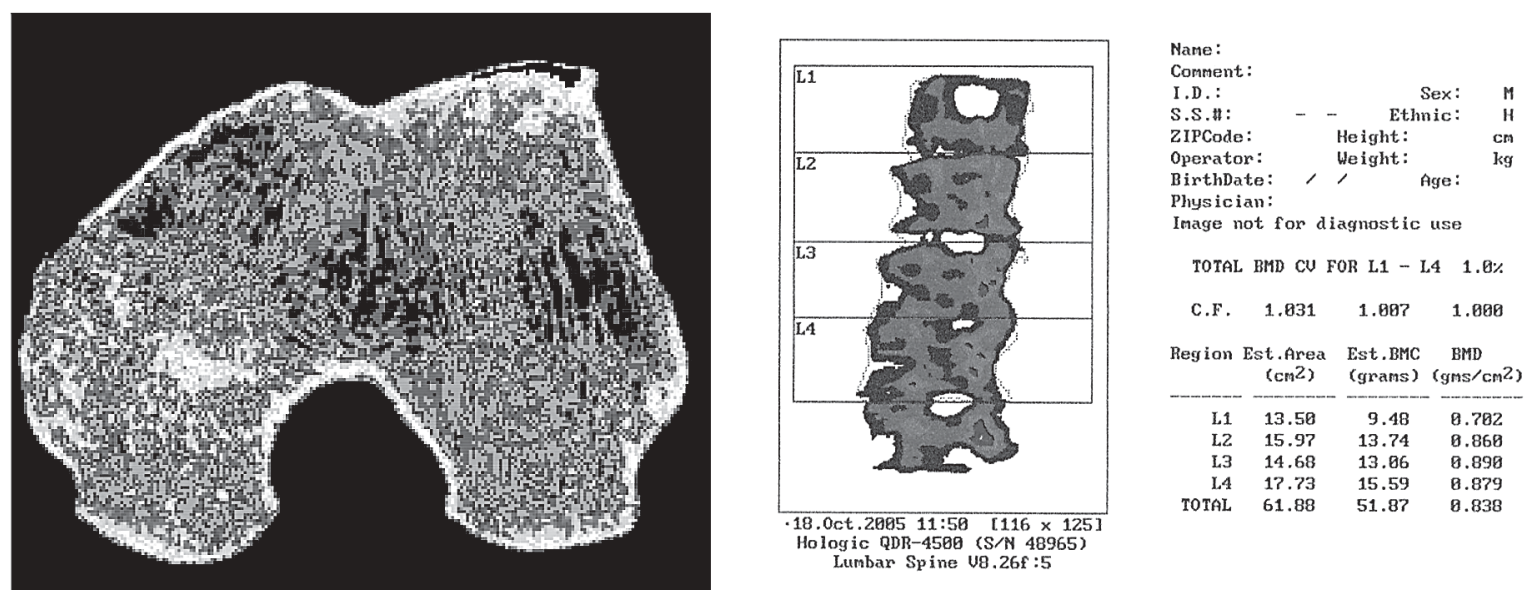

Fig. 3: bone mineral density analysis from human bones with peripheral quantitative computed tomography (left) and photondensitometry (right). 
TABLE II

Events in the history of Southern Patagonia

\begin{tabular}{|c|c|}
\hline Chronology & Events \\
\hline $11000 \mathrm{BP}$ & First settlers of Southern Patagonia \\
\hline $8000 \mathrm{BP}$ & Opening of the Strait of Magellan \\
\hline 1520 & Discovery of the Strait of Magellan \\
\hline 1584 & $\begin{array}{l}\text { Attempt to settle in the Strait (Campaign } \\
\text { by Sarmiento de Gamboa) }\end{array}$ \\
\hline 1781 & $\begin{array}{l}\text { Foundation of Floridablanca, Santa Cruz, } \\
\text { Argentina }\end{array}$ \\
\hline 1852 & Foundation of Punta Arenas, Chile \\
\hline 1868 & Beginning of the hunting of sea-wolves \\
\hline 1870 & $\begin{array}{l}\text { Foundation of Anglican Mission, Ushuaia, } \\
\text { Tierra del Fuego }\end{array}$ \\
\hline 1885 & $\begin{array}{l}\text { Foundation of Río Gallegos, Santa Cruz, } \\
\text { Argentina }\end{array}$ \\
\hline 1893 & $\begin{array}{l}\text { Foundation of Mission "La Candelaria", } \\
\text { Tierra del Fuego }\end{array}$ \\
\hline
\end{tabular}

The Native-European contact in Southern Patagonia can be understood as a complex process of interaction that took several hundreds of years. The first contact occurred on the coast (Fugassa \& Guichón 2004) and it was many years later that the Europeans moved inland (Amador 1990). Table II summarizes some important events in the history of the region.

One of the presumptions about the first Native-European encounter could be connected to the role of the indirect contact as suggested by Dobyns (1993). Thus Borrero (1992) speculates that the size of the population at pre-contact time in Tierra del Fuego might have declined. Nevertheless, considering the number of inhabitants, the dynamics of these hunter-gatherer populations, and the climatic conditions in the area (mainly strong westerly winds) our expectations for the dispersion of infectious diseases transmitted by air (such as tuberculoses, influenzavirus, measles, and adenovirus) are low (Fugassa \& Guichón 2005). If our speculations were confirmed, the population size observed by the first explorers would not have been modified by the arrival of the European people.

The other scenario in this process is the direct contact between the native people and the European colonizers. This type of contact started in 1850, when the Anglicans came into the Beagle Channel to establish their mission, which was finally founded in Ushuaia. The daily lifestyle of the natives was altered. The dispersion of diseases was one of the contributory factors in the changes initiated with the interethnic contact among natives, missioners, sailors, whale hunters, and the first Chilean colonizers. The historical works and ethnographic sources (Bridges T 1891a, b, 1893, Braun Menéndez 1939, Emperaire 1963, Belza 1975, Bridges E 1975, Canclini 1986) reveal the exposure of Beagle Channel native populations to a di- versity of diseases, with a predominance of measles and tuberculosis. Other diseases, like syphilis, might also have been transmitted to native people.

The last quarter of the XIX century produced significant changes in the Native's health, due to both colonization and the development of animal husbandry (particularly the expansion of sheep according to the demand of the international market). The extinction of Fueguin populations was then irreversible, and the role of disease was important. Death due to infectious diseases was a fundamental part of this change (Gallardo 1910, Braun Menéndez 1939, Gusinde 1951, 1982, Canclini 1986, Martinic 1990, García Moro 1992, Garcia Moro et al. 1997). Direct reasons, such as native massacres in the hands of gold hunters, could be mentioned, but indirect modes were central too. The alteration of material and spiritual lifestyle of these populations was a manifold process, including social organization, diet, territory, and culture. Therefore more detailed and integrated historical and bio-archeological studies are necessary.

\section{Cases of study}

In 2005, we started doing fieldwork in two sites: "Nombre de Jesus", the first Spanish settlement founded by Sarmiento de Gamboa in the Strait of Magellan in 1584; and "La Candelaria" Mission in Río Grande founded in 1896.

\section{Nombre de Jesus (XVI c)}

The aim of the Spanish expedition was to establish two settlements in the Strait of Magellan to block the passage of English corsairs. In 1581, 16 ships and 2408 people onboard (among these men, women, and a few children) set sail from Spain. The following year, 2225 people arrived at Rio de Janeiro, Brazil. Despite their attempt to continue with the voyage, the expedition stayed in the country for over a year. The expedition then suffered a process of disintegration characterized by disagreement, desertions, and theft. Consequently, six vessels departed from Brazil on the 1 December 1583 . Only 400 people arrived at the Strait and founded "Nombre de Jesus" in 1584. Three years later, in January 1587, the English pirate Thomas Cavendish found 18 survivors, although decided to rescue only one of them (Fernandez 1990).

Sarmiento de Gamboa and the colonist rescued by Cavendish constitute the only source of information that helps us understand what happened at the two settlements, "Nombre de Jesus" and "Rey Felipe". Both survivors' statements agree about the scarcity of food. For this reason, some researchers (Martinic 1983) speculate that these people may have starved to death, while others (Fernandez 1990) sustain that the environmental resources could have been sufficient to supply both "Nombre de Jesus" and "Rey Felipe".

Until now, the location of the first settlement has been unknown. The recent finding of four skeleton burials may

\footnotetext{
${ }^{2}$ Dr Senatore began to work in "Nombre de Jesus" in 2004 and invited us to join one year later.
} 
TABLE III

Height estimated for young adult skeleton found in Nombre de Jesus (Trotter \& Glesser 1958, 1977)

\begin{tabular}{lrrr}
\hline Height & \multicolumn{1}{c}{ Femur } & Femur + Tibia & \multicolumn{1}{c}{ Humero } \\
\hline Skeleton 2 & $168,3 \pm 3,27$ & $170 \pm 2,99$ & $168,9 \pm 4,05$ \\
Skeleton 3 & $165 \pm 3,72$ & $166,8 \pm 3,55$ & $173,1 \pm 4,55$ \\
Skeleton 4 & $182 \pm 3,27$ & $182,4 \pm 2,99$ & $175,9 \pm 4,05$ \\
\hline
\end{tabular}

indicate that we have found "Nombre de Jesus". The cultural position of the skeletons, the $\mathrm{C}^{14}$ information of skeleton NJ-1 (Ua-22946: $475 \pm 45$ BP), and the presence of Spanish mortuary elements support this idea. In Fig. 4 we can see the four skeletons recovered, all of them aligned with their heads pointing eastwards. In a first analysis of age and sex, we have determined that three of them could be young adults at the time of death (two male and one female NJ-3), and one skeleton NJ-1 of a child (10 to 14 years old). The height of the three adult skeletons has been calculated (Table III) according to Trotter and Glesser (apud Borgognini Tarli \& Pacciani 1993).

Considering the aid letters written by Sarmiento de Gamboa to King Felipe II, one of our hypothesis is that the inhabitants of "Nombre de Jesus" suffered some kind of nutritional stress. We are still working on the assessment of the observational signs of the bones. Although we have not found porotic hyperostosis or criba orbitalia, the skeletons number two (NJ-2), three (NJ-3), and four (NJ-4) present femoral hyperostosis (Perez Martín et al. 1999) which has been questioned as a nutritional stress indicatior. In relation to functional pathologies, only skeleton three (NJ-3) shows lumbar scoliosis.

Moreover, skeleton NJ-1 presents incisives morphology similar to "shovel" tooth frequently found in Mon- goloid populations (Brothwell 1993). In Fig. 5 the incisives of the four individuals can be observed. Future DNA studies of NJ-1 and new radiocarbon data of the other skeletons could help us to reject or accept the idea of both Spanish and Natives burials in the same graveyard. The radiocarbon information for $\mathrm{NJ}-1$, the same orientation and depth of graves, and the cultural material associated to NJ-4 (ceramic and metal elements) could support the contemporaneity of the burials (Senatore et al 2005).

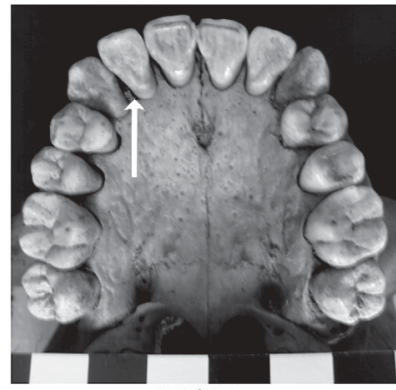

$\mathrm{NdJ} 1$

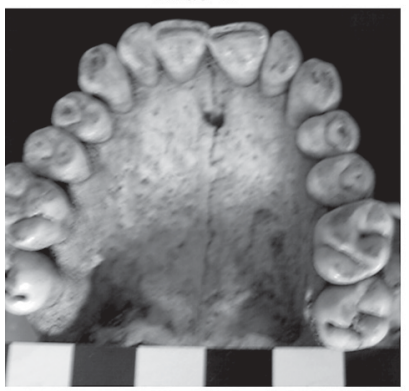

$\mathrm{NdJ} 3$

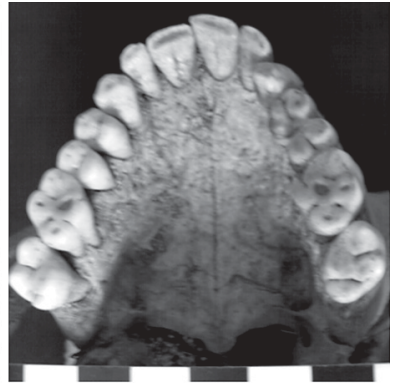

NdJ 2

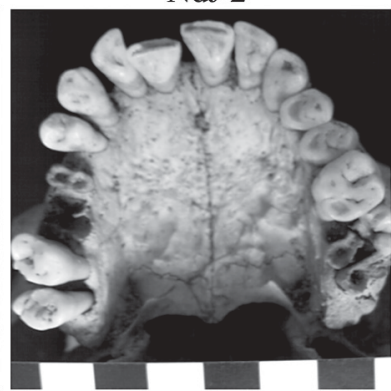

$\mathrm{NdJ} 4$
Fig. 5: incisives of the four individuals (NJ-1, NJ-2, NJ-3, NJ-4).

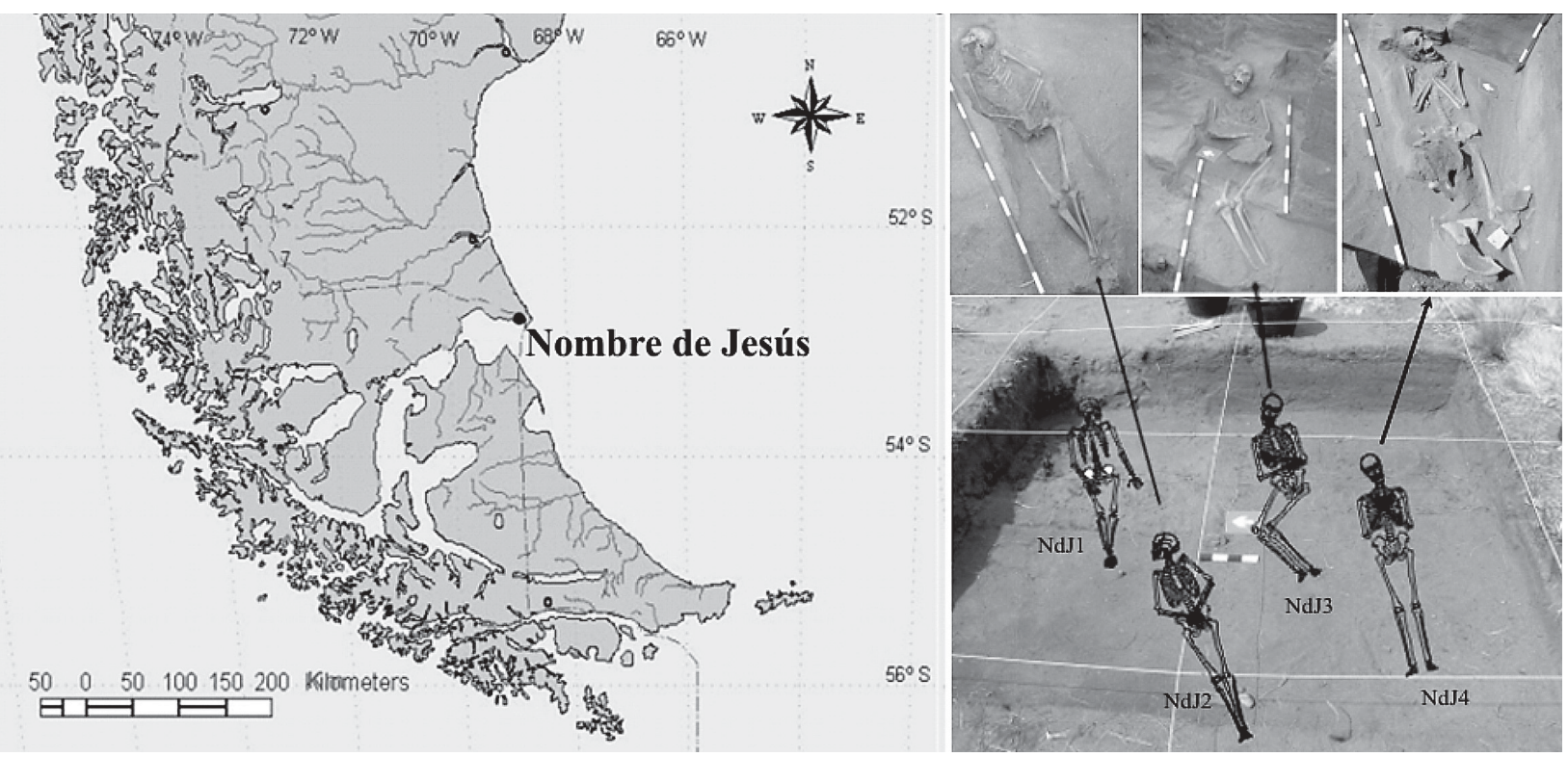

Fig. 4: first Spanish settlement in the Strait of Magellan, 1584-1587, Sarmiento de Gamboa, "Nombre de Jesus", Cabo Virgenes. 
In the case of long bones, some epiphyses show incomplete fusion. Considering the ages at death estimated for these young adult individuals, the epiphysal fusion seems retarded, fundamentally in the legs. Moreover, the long bones of legs present bilateral periostitis, with reddish stains. Through forensic methods, our next step is to work on the detection of human hemoglobin on these bone surfaces. Dental characteristics, such as pre-mortem dental loss and alveolar retraction, may also add to future discussion about the presence of scurvy as already mentioned in the historical documentation available (Sarmiento de Gamboa 1950).

Some structural characteristics of bones, principally $\mathrm{BMD}$ and cortical area index, are good indicators of nutritional stress (Larsen 1997, 2002, Ruff 2000, Ruff \& Larsen 2001). To evaluate architectonical bone alterations, we are doing bone photon-densitometry, whose preliminary results have shown compatible values with osteopenia or osteoporosis in all skeletons. Furthermore, peripheral Quantitative Computed Tomography (pQCT) has contributed to the evaluation of the cross-sectional structure of long bones, through cortical area and second moments of inertia. So far, we have found that all skeletons have endocortical alterations, with a significant reduction of the cortical area in tibia and radius (Fig. 6). Moreover, some cortical alterations have been observed in long bones through tomographical slices and digital X-ray. This last technique revealed Harris lines in the tibias of skeleton NJ-1. Finally, we are working on paleoparasilogical studies of archaeological sediments found at "Nombre de Jesus" (see Fugassa et al. in this issue).

\section{La Candelaria (XIX c.)}

As part of the strategy of colonization, the Salesian Mission "La Candelaria" (Fig. 7) was settled near presentday Rio Grande City, Tierra del Fuego, in 1893. The pres-

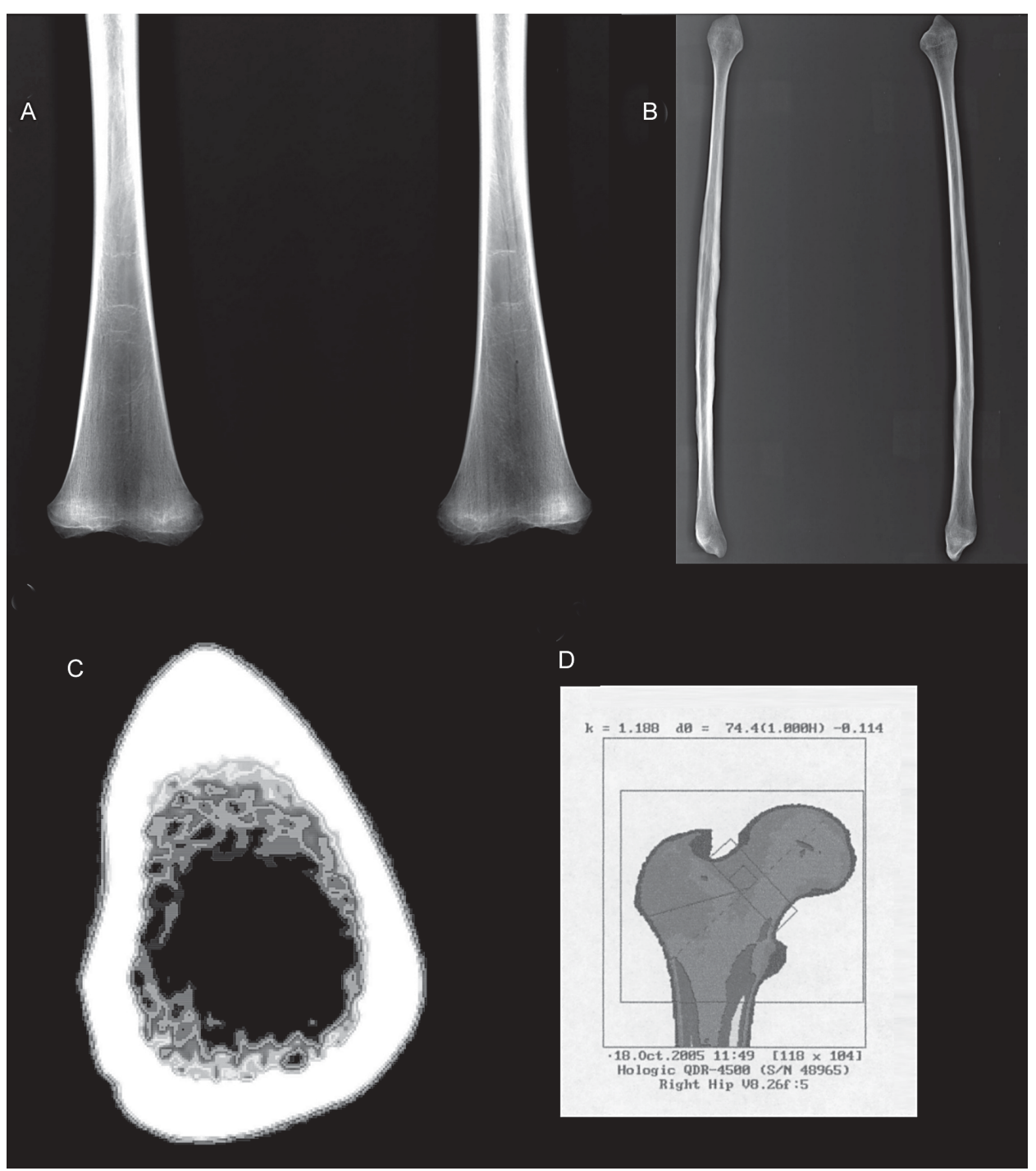

Fig. 6: paleopathological bone analyses from "Nombre de Jesus". A: Harris lines in both femoral of skeleton 1; B: bilateral periostitis in skeleton 4 ulna; C: pQCT images showed reduction of cortical area; D: analysis of BMD with photondensitometry, showed osteoporotic values in femoral neck of skeleton NJ-2. 


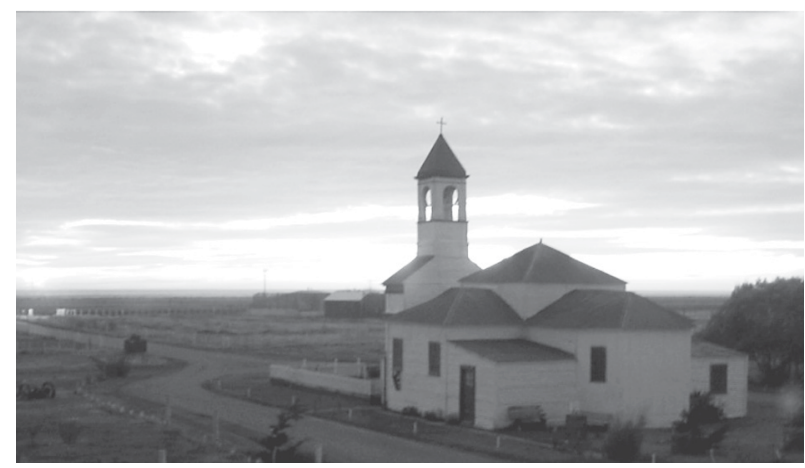

Fig. 7: the Salesian Mission La Candelaria, Río Grande, Tierra del Fuego.

ence of European people on the island brought about the movement of human groups altering their territoriality, and provoking new intertribal wars and the aggravation of previous conflicts (Gallardo 1910, Gusinde 1951, 1982, García Moro 1992).

Moreover, the sheep started competing and displacing the guanaco (Lama guanicoe) for grazing. As the guanaco constituted a basic resource for the Selk'nam (Onas), the Natives hunted sheep as a new nutritional source. In this context the European people started capturing and murdering the Selk'nam. Therefore, the "legal authority", the new land owners and missioners, implemented the strategy of taking the natives to the Missions. Considering this new scenario some authors sustain that the decrease in Native population size is related to the inclusion of the Natives into the Mission and the subsequent dispersion of infectious diseases (Gallardo 1910, Braun Menéndez 1939, Gusinde 1951, 1982, Canclini 1986, Martinic 1990, García Moro 1992).

It has been suggested that the high mortality, fundamentally due to infectious diseases, was the most direct cause of the Selk'nam "extinction" (Garcia Moro 1992). The historical documentation will certainly provide other aspects of the interethnic contact and its effect on health. One of our aims is to evaluate and discuss death caused by infectious diseases in the Selk'nam population of "La Candelaria" Mission, and the subsequent native disappearance. To study evidence in an interdisciplinary framework is our immediate challenge.

An examination of the period 1896-1931 has already been carried out through the Diary of the Mission (Book 1, 1896-1902), the Baptism Book (1896-1913), and the Book number II of Demises (1902-1931). According to these books, Native deaths in the mission amounted to 223 individuals. Most of them were Selk' nam, with similar percentages for both sexes, and certain predominance of 4 to 12 year-old children. Since specific information about the causes of decease for the period 1897-1902 does not exist, the death profile (age, sex, seasonally of decease, etc.) has been compared with the period 1902-1931, for which there is specific data. Moreover, diverse ethnographical and secondary sources have been analyzed in order to provide a context to the obtained information.

\section{Prospects}

We have presented the general framework and briefly mentioned our new findings ("Nombre de Jesus" - XVI c) and some recent results. As has been commented above, we are working a long different lines of information (human taphonomy, bone paleopathology, paleoparasitology, and historical documents) from several archaeological sites and bone collections of the region. In this context, the future perspectives for our work imply a schedule oriented to: (a) continue the study of the human bone record, as a necessary source of information to make inferences about changes in health and lifestyle; (b) revise the standards that have been used up to the present in order to develop comparative studies that consider a wider regional scale, such as suggested by Steckel and Rose (Steckel et al. 2002); (c) identify, among the osteological collections, material that could provide information about possible changes in health attributed to Native-European contact; (d) conclude our fieldwork at "Nombre de Jesus" archaeological site. The studies on recovered materials started through non-destructive techniques (CT, pQCT, DEXA, and $\mathrm{Rx}$ ) showing nutritional stress. At the same time, it is necessary to evaluate the probable presence of scurvy. Moreover, we hope that DNA analyses and radiocarbon data support the hypothesis of a Native-European mixed graveyard on the Magellan Strait in 1584. Stable isotopes information may offer a first approximation to the diet of the recovered individuals; (e) work with historical research, adding other sources of information related to "La Candelaria" Mission and Salesian Mission of Dawson Island (Chile); (f) continue the paleoparasitological studies, analysing pre and post-contact materials.

In the last years, it has been suggested that the comprehension of the health status of the past populations is the result of a complex system of cultural and environmental variables, which should be included for a better interpretation (Steckel et al. 2002). Our comprehension of the changes in the health of Southern Patagonian populations requires research into the complex process (before, during, and after) of Native-European contact. This implies a challenge that we expect to answer with the help of those colleagues who may be interested in the extreme Southern Hemisphere.

\section{ACKNOWLEDGEMENTS}

To those who supported us in this work: A Araújo (Fiocruz, Br.); C Rodríguez Martín (OAMyC, Tenerife, Sp.); G Denegri y Sardella N (Conicet, UNMdP, Ar.); JL Ferretti (Conicet, UNR, Ar.); LA Borrero (Conicet, UBA, Ar.); MX Senatore (Conicet, UBA, Ar.); I Cruz (UNPA, Ar.); S Muñoz (Conicet-UBA, Ar.); T Civalero (INAPL, Conicet, Ar.); S Mendonça de Souza (Fiocruz, Br.); Hospital Privado de Comunidad de Mar del Plata (Drs Varella and Tomassiello, Ar.); Centro de Estudios del Metabolismo Fosfocalcico (Rosario-Ar.); Instituto Radiológico de Mar del Plata (Dr Carlos Capiel, Ar.) who facilitated the use of X-ray equipment. Museo Regional Provincial Padre J. Molina, Universidad Nacional de la Patagonia Austral, Argentina. To Father Juan Ticó and the authorities of Misión Salesiana, Río Grande, Tierra del Fuego. To Instituto de la Patagonia, Punta Arenas, Chile. To Patricia Palacio for her collaboration making tables and maps. To Daniela Dupás and Sandra Baliño, who helped us translate this work. Especially to our families, for their support and encouragement. 


\section{REFERENCES}

Amador TA 1990. La población indígena de la Patagonia en el Boletín Salesiano. Aproximación etnohistórica. In JR Bárcemas, Culturas Indigenas de la Patagonia, S.1: Turner/ Sociedad Estatal Quinto Centenario, España, p. 201-204.

Armelagos GJ, Brown PJ, Turner B 2005. Evolutionary, historical, and political perspectives on health and disease. Soc Sci Med 61: 755-765.

Aspillaga E, Ocampo C 1996. Restos óseos humanos de la isla Karukinka (Seno Almirantazgo, Tierra Del Fuego), informe preliminar. An Inst Patagonia 24: 153-161.

Aspillaga E, Ocampo C, Rivas P 1999. Restos óseos humanos de contextos arqueológicos del área de Navarino: indicadores de estilo de vida en indígenas Canoeros. An Inst Patagonia 26: 123-136.

Barberena R 2002. Los Límites del Mar. Isótopos Estables en Patagonia Meridional, Thesis, Sociedad Argentina de Antropología, Buenos Aires, 331 pp.

Barrientos G, Béguelin M, Bernal V, del Papa M, Ghidini G, Gonzalez P, Gordón F, Martínez L, Perez I 2005. Una perspectiva biogeográfica en el estudio de la variación biogeográfica humana: dos ejemplos de Patagonia. Programa y resúmenes de las VI Jornadas de Arqueología de la Patagonia, Punta Arenas, Chile, p. 20-21.

Behrensmeyer AK, Hook RW 1992. Paleoenvironmental contexts and taphonomic odes. In AK Behrensmeyer, JD Damuth, WA Dimichele, R Potts, HD Sues, SL Wing (eds), Terrestrial Ecosistems Through Time. Evolutionary Paleoecology of Terrestrial Plants and Animals, University of Chicago Press, Chicago, p. 16-136.

Behrensmeyer AK, Kidwell SM, Gastaldo R 2000. Taphonomy and paleobiology. In DH Erwin, SL Wing (eds), Deep Time. Paleobiology's Perspective. Paleobiol 26 (Suppl.): 103-147.

Belza JE 1975. En la isla del fuego Vol 2: Colonización, Publicación del Instituto de Investigaciones Históricas de Tierra del Fuego, Patagonia, 366 pp.

Borgognini Tarti S, Pacciani E 1993. I Resti Umani nello Scavo Archeologico Metodiche di Recupero e Studio, Bulzoni Editore, Italia, $319 \mathrm{pp}$.

Borrero LA 1992. El registro arqueológico del contacto: enfermedad y discontinuidad poblacional. Trabajo presentado al Simposio Encuentro de dos Culturas, Centro Cultural General San Martín, Buenos Aires, p.1-6.

Borrero LA 1996 The Pleistocene-Holocene transition in Southern South America. In Laurence G Strauss, Humans at the End of Ice Age: The Archaeology of the PleistoceneHolocene Transition, Plenum, New York, p. 339-354.

Borrero LA 2004. Arqueología en América del Sur. ¿Se requiere un acercamiento teórico especial? In G Politis, RD Peretti (eds), Teoría Arqueológica en América del Sur, INCUAPAUNICEN, Argentina, p. 71-84.

Borrero LA 2005. The archeology of the Patagonian deserts hunter-gatherers in a cold desert. In P Veth, M Smith, P Hiscock (eds), Desert Peoples, Archaeological Perspectives, Blackwell Publishing, New York, p. 142-158.

Borrero LA, Muñoz AS 1999. Tafonomía en el Bosque Patagónico. Implicaciones para el estudio de su explotación y uso por poblaciones humanas de cazadores-recolectores. In
Soplando en el Viento, Actas de Las Terceras Jornadas de Arqueología de la Patagonia, Instituto Nacional de Antropología y Universidad Nacional del Comahue, Neuquén y Buenos Aires, p. 43-56.

Borrero LA, Guichón RA, Tykot R, Kelly J, Prieto A, Cárdenas P 2001. Dieta a partir de isótopos estables en restos óseos humanos de Patagonia Austral. Estado Actual y perspectivas. An Inst Patagonia, serie Cs Hs 29: 119-127.

Braun Menéndez A 1939. Pequeña Historia Fueguina, Emecé, Buenos Aires, 315 pp.

Bridges EL 1975. El Último Confín de la Tierra, Marymar, Buenos Aires, 520 pp.

Bridges T 1891a. Datos sobre Tierra del Fuego comunicados por el reverendo Thomas Bridges. Rev Museo de La Plata 3: $19-25$.

Bridges T 1891b. Datos sobre Tierra del Fuego comunicados por el reverendo Thomas Bridges. Rev Museo de La Plata 3: 313-320.

Bridges T 1893. La Tierra del Fuego y sus habitantes. Bol Inst Geogr Argentino 15: 221-241.

Brothwell DR 1993. Desenterrando Huesos, la Excavación, Tratamiento y Estudio de Restos del Esqueleto Humano, Fondo de Cultura Económica, España, 287 pp.

Canclini A 1986. Tierra del Fuego, su Historia en Historias, Galerna, Buenos Aires, 325 pp.

Cocilovo JA, Guichón RA 1985 1986. Propuesta para el estudio de las poblaciones aborígenes del Extremo Austral de Patagonia. An Inst Patagonia Ser Cs Sc 16: 111-123.

Cruz I 2004. Tafonomia de huesos de aves en Punta Medanosa (Dpto Puerto Deseado, Santa Cruz, Argentina). In MT Civalero, PM Fernández, AG Guraieb (eds), Contra Viento y Marea. Arqueología de la Patagonia, Inst. Nac. De Antr. y Pens. Lat.- Soc. Arg, Buenos Aires, p. 445-449.

Cutler AL, Behrensmeyer AK, Chapman RE 1999. Environmental information in a recent bone assemblage: roles of taphonomic processes and ecological change. Palaeogeography, Palaeoclimatology, Palaeoecology 149: 359-372.

Dobyns HF 1993. Disease transfer at contact. Ann Rev Anthropol 22: 273-291.

Emperaire J 1963. Los Nómades del Mar. Ser Indígena. Portal de las Culturas Originarias de Chile, Universidad del Chiel, Santiago, 263 pp.

Fernández J 1990. Análisis de las causas concurrentes al fracaso de las Colonias Españolas de 1584 en el estrecho de Magallanes, Patagonia Austral. In JR Bárcenas, Culturas Indígenas de la Patagonia, Ed. Quinto Centenario, España, 273 pp.

Fugassa MH 2005. New paleoparasitological analyses of human coprolites from Southern Patagonia. Paleopathol Newsl 132: 25 .

Fugassa MH, Guichón RA 2004. Transición epidemiológica en Tierra del Fuego: el contacto indirecto y las enfermedades infecciosas entre 1520 y 1850. Magallania 32: 99-114.

Fugassa MH, Guichón RA 2005. Análisis paleoparasitológico de coprolitos hallados en sitios arqueológicos de Patagonia Austral: definiciones y perspectivas. Magallania 33: 1319.

Gallardo CR 1910. Los Onas, Cabaut y Cia., Buenos Aires, $395 \mathrm{pp}$. 
Garcia Guraieb S, Gonzalez P, Bernal V 2005a Estructura de sexo y edad de la muestra de restos humanos del holoceno tardío del Lago Salitroso (Santa Cruz, Argentina). Programa y resúmenes de las VI Jornadas de Arqueología de la Patagonia, Punta Arenas, Chile, p. 49.

Garcia Guraieb S, Goñi R, Bosio L 2005b. Lesiones traumáticas en un entierro del Lago Salitroso. Programa y resúmenes de las VI Jornadas de Arqueología de la Patagonia, Punta Arenas, Chile, p. 49.

Garcia Moro C 1992. Reconstrucción del proceso de extinción de los Selk'nam a través de los libros misionales. An Inst Patagonia 21: 33-46.

Garcia Moro C, Hernández M, Martinic M 1993. La nupcialidad en Magallanes (1885-1920) estado civil y edad matrimonial. An Inst Patagonia 2: 37-48.

Garcia Moro C, Hernandez M, Lalueza C 1997. Estimation of the optimum density of the selk'nam form Tierra del Fuego: inferences about human dynamics in extreme environments. Am J Human Biol 9: 699-708.

González JR, Martínez-Abadías N, Van Del Molen S, GarciaMoro C, Dahinten S, Hernández M 2004. Hipótesis acerca del poblamiento de Tierra del Fuego-Patagonia a partir del análisis genético-poblacional de la variación craneofacial. Magallania 32: 79-98.

Guichón RA 1995. Vías de análisis, problemas y discusiones en la antropología biológica de Tierra del Fuego. Relac Soc Argentina Antropol XX: 239-256.

Guichón RA 2000. Agenda para una Evaluación en la Antropología Biológica de Patagonia Austral. In Desde el País de los Gigantes, Perspectivas Arqueológicas en Patagonia, UNPA, Argentina, p. 99-108.

Guichón RA 2002. Biological Anthropology of Southern Patagonia. In C Briones, JL Lanata (eds), Archaeological and Anthropological Perspectives on the Native Peoples of Pampa, Patagonia, and Tierra del Fuego to the Nineteenth Century, Greenword Pub., US, Chapter 2, p. 13-29.

Guichón RA, Barberena R, Borrero LA 2001. ¿Dónde y cómo aparecen los restos óseos humanos en Patagonia Austral? Ana Inst Patagonia (Serie CsHs) 29: 103-118.

Guichón RA, Muñoz AS, Borrero LA 2000. Datos para una tafonomía de restos óseos humanos en Bahía San Sebastián, Tierra Del Fuego. Relac Soc Argentina Antropol XXV: $297-$ 311.

Gusinde M 1951. Hombres Primitivos en la Tierra del Fuego (de Investigador a Compañero de Tribu), Publicaciones de la Escuela de Estudios Hispano-americanos de Sevilla, España, 398 pp.

Gusinde M 1982. Los Indios de Tierra del Fuego. Tomo I. Vol $I$, Centro Argentino de Etnología Americana, Conicet, Buenos Aires, 1140 pp.

Hernández M, Garcia Moro C, Martinic M 1998. Evolución demográfica de la población de Tierra Del Fuego (Región De Magallanes), An Inst Patagonia 26: 41-68.

Lalueza C 1995. Recuperación de DNA Mitochondrial y Caracterización de Variabilidad en Poblaciones Antiguas, $\mathrm{PhD}$ Thesis, Universidad de Barcelona, Barcelona, $265 \mathrm{pp}$.

Larsen CS 1997. Bioarchaeology: Interpreting Behavior from Human Skeleton, Cambridge University Press, Cambridge, $474 \mathrm{pp}$.
Larsen CS 2002. Bioarchaeology: the lives and livestyles of past peoples. J Archaeol Res 10:119-165.

Lukacs JR 1989. Dental paleopathology: methods for reconstructing dietary patterns. In MY Iscan, KAR Keneddy (eds), Reconstruction of Life From the Skeleton, AR Liss, New York, p. 261-286.

Martin FM, Barbarena R, Guichón RA 2004. Erosión y huesos humanos. El caso de la localidad Chorrillos, Tierra del Fuego. Magallania 32:125-142 .

Martinic M 1983. El Reino de Jesús. La efímera y triste historia de una gobernación en el Estrecho de Magallanes (15811590). An Inst Patagonia 14: 7-32.

Martinic M 1990. El genocidio Selk'nam: nuevos antecedentes. An Inst Patagonia 19: 23-28.

Mendonça De Souza SMF, Carvalho DM, Lessa A 2003. Paleoepidemiology: Is there a case to answer? Mem Inst Oswaldo Cruz 98 (Suppl.1): 21-27.

Pérez Martín S, Antona Montoro AM, Rodríguez González AI, González Martí A 1999. Macroporosidad del cuello del fémur en la población hispanomusulmana de San Nicolás (Murcia s. XI-XIII). Actas V Congreso Nacional de Paleopatología, Alcalá La Real, España, p. 6.

Pérez Pérez A, Lalueza Fox C 1992. Indicadores de presión ambiental en aborígenes de Fuego-Patagonia. Un reflejo de la adaptación a un ambiente adverso. An Inst Patagonia 21: 99-108.

Ruff CB 2000. Biomechanical analyses of archeological human skeletal samples. In MA Katzemberg, SR Saunders (eds), Biological Anthropology of the Human Skeleton, Wiley-Liss, New York, p. 71-102.

Ruff CB, Larsen CS 2001. Reconstructing behavior from Spanish Florida: the biomechanical evidence. In CS Larsen, Bioarchaeology of Spanish Florida: The Impact of Colonialism, University Press of Florida, Gainesville, p. 13145.

Sarmiento de Gamboa P 1950. Viajes al Estrecho de Magallanes (1579-1584) Recopilación de sus Relaciones sobre los dos Viajes al Estrecho y de sus Cartas y Memorias. Con un Apéndice Documental sobre su Vida y sus Viajes, Tomo II, Emece Editoriales, Buenos Aires, 507 pp.

Senatore MX, De Nigris M, Guichón RA, Palombo P 2005. Arqueología en la Ciudad del Nombre de Jesús: vida y muerte en el Estrecho de Magallanes hacia fines del siglo XVI, Resúmenes VI Jornadas de Arqueología de la Patagonia, Punta Arenas, Chile, p. 84.

Steckel RH, Rose JC, Larsen CS, Walker PL 2002. Skeletal health in the Western Hemisphere from $4000 \mathrm{BC}$ to the present. Evolut Anthropol 11: 142-155.

Suby JA, Guichón RA 2004. Densidad mineral ósea y frecuencia de hallazgos en restos humanos en el Norte de Tierra del Fuego. Intersecciones en Antropol 5: 95-104.

Wood JW, Millner GR, Harpending HC, Weiss KM, 1992. The osteological Paradox. Problems of inferring prehistoric health from skeletal samples. Cur Anthropol 33: 343-369.

Wing SL, Sues HD, Potts R, Dimichele WA, Behrensmeyer AK 1992. Evolutionary Paleoecology. In AK Behrensmeyer, JD Damuth, WA Dimichele, R Potts, HD Sues, SL Wing (eds), Terrestrial Ecosystems through Time: Evolutionary Paleoecology of Terrestrial Plants and Animals, University of Chicago Press, Chicago, p. 1-14. 
